DOI: 10.15503/onis2014-13-22

\title{
KONSEKWENCJE GLOBALISTYCZNEGO MODELU NAUKI
}

\author{
Kamil Błaszczyński, kamil.b.1988@wp.pl \\ Uniwersytet Wrocławski \\ Pl. Uniwersytecki 1, 50-137 Wrocław
}

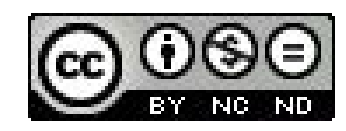

\section{STRESZCZENIE}

Celem niniejszego artykułu jest opis i wyjaśnienie idei globalistycznej nauki oraz stosunkowo nowego zjawiska jakim jest globalna nauka. Następnie opis i wyjaśnienie procesu implementacji oraz ukonstytuowania się globalistycznej idei nauki oraz globalnego modelu nauki (GMN) w Polsce i na świecie. Opis uzupełniony jest o konsekwencje dominacji GMN dla funkcjonowania polskiego szkolnictwa wyższego. Ostatnim celem jest opis i wyjaśnienie procesu stratyfikacji uczonych w skali lokalnej oraz globalnej. Narracja artykułu osadzona będzie na tle teoretycznym paradygmatu strukturalnego funkcjonalizmu oraz teorii konfliktu.

Słowa kluczowe: globalna nauka, globalistyczna nauka, polskie szkolnictwo wyższe, kapitał, ład akademicki, scientobryta.

\section{Consequences of Global Model of Science}

\section{Abstract}

The purpose of this article is to describe and explain the idea of globalistic science and a relatively new phenomenon named global science. Next follows a description and explanation of the implementation process and the constitution of the globalistic idea of science and the Global Model of Science (GMS) in Poland and in the World. Description is supplemented with the consequences of dominance of the GMS for the functioning of Polish higher education. The last aim is to describe and explain the process of stratification of scholars on the local and the global scale. Narration of the article will be set on the theoretical background of the structural functionalism and conflict theory paradigms.

Key words: global science, globalistic science, polish higher education, capital, academical order, scielebrity.

Związki między ideologiami gospodarczymi oraz światem akademickim były już szeroko dyskutowane i opisywane w prasie socjologicznej, pedagogicznej i filozoficznej. ${ }^{1}$ Nie podjęto natomiast próby systematyzacji dotychczas wypracowanej wiedzy oraz nie spróbowano nazwać nowych jakości jakie wytworzyły się w wyniku sprzężenia dwóch wspomnianych fenomenów. Celem niniejszego tekstu jest uzupełnienie owej luki w wiedzy oraz zaproponowanie pewnej interpretacji szeregu zjawisk, które będą poruszane w tekście.

\section{Problem gŁówny}

Główne zagadnienia poruszane w tekście, pomimo iż znane i przywoływane na kanwie literatury przedmiotu, wymagają redefinicji i reinterpretacji, aby móc stworzyć logiczny, spóiny i pełny obraz problemu. Dookreślenia wymagają przede wszystkim pojęcia globalnej nauki oraz idei globalistycznej nauki. Dopiero po nakreśleniu definicji najważniejszych pojęć będzie możliwe udzielnie odpowiedzi na główne pytanie problemowe: Jakie konsekwencje dla ładu akademickiego w Polsce wygenerowała globalistyczna idea nauki?

Ze względu na to, iż dotychczas nikt nie podejmował próby odpowiedzi na pytanie czym jest globalistyczna idea nauki, opisania i wyjaśnienia wymaga proces krystalizowania owej koncepcji ideologicznej. To natomiast rodzi pytania o realne inicjatywy i narzędzia służące jej zaszczepianiu i rozpowszechnianiu. Podobna sytuacja występuje w przypadku zjawiska nauki globalnej, które samo w sobie ma cechy aksjomatu, aczkolwiek konieczne jest zarówno wskazanie fundamentów tworzących naukę globalna, jak i realne konsekwencje, które ona spowodowała. Po nakreśleniu podstaw teoretycznych będzie możliwe końcowe udzielnie odpowiedzi na pytanie podstawowe dotyczące konsekwencji.

1 Wśród czołowych badaczy i pisarzy wymienić należy m. in. Zygmunta Baumana, Teresę Bauman, Noama Chomskiego, Henriego A. Giroux, Lecha Witkowskiego, Mirosława J. Szymańskiego, Eugenię Potulicką, Joannę Rutkowiak, Zbigniewa Kwiecińnkiego, Zbyszko Melosika, Darię Hejwosz oraz Bogusława Śliwerskiego. 


\section{RóŻNICA MIĘDZY TYM CO GLOBALNE, A TYM CO GLOBALISTYCZNE W NAUCE}

Globalna nauka określa fakt zastany, mówiący o tym, że w wyniku splotu wielu czynników powstała globalna struktura akademicka, która wytwarza wiedzę naukową na skalę światową. Zachodzą w niej nieustannie żywe, dynamiczne i wielotorowe interakcje służące realizacji różnorodnych interesów jednostkowych, instytucjonalnych i ponadnarodowych (np. interes gospodarczy Unii Europejkkiej). Wśród najważniejszych elementów składających się na zjawisko nauki globalnej można wymienić:

- gwałtowny rozwój i praktyczna implementacja technik i technologii informacyjnych²;

- $\quad$ procesy globalizacyjne (zarówno w sferze społecznej, kulturowej, gospodarczej, ekonomicznej i politycznej).

Globalistyczną ideą nauki natomiast określać należy pogląd ideologiczny, głoszący, iż jedynie nauka uprawiana w perspektywie globalnej jest nauką sensu stricto i tylko ona ma obecnie jakąkolwiek wartość poznawczą. Zachowuje ja, ponieważ pozwala śledzić najnowsze globalne „,mody" i trendy w wybranych dyscyplinach wiedzy. Sprawia, iż „"wspólnota" uczonych posiada względnie egalitarny charakter, choćby w dostępie do danych, zrównując się w warstwie językowej. Wyposażającją w najnowsze pojęcia, teorie, koncepcje i narzędzia badawcze oraz standaryzując (unifikując) wymogi dotyczące choćby modelu i standardu wypowiedzi naukowej. W całości stanowić to może uniwersalny transnarodowy wzór metodologiczny ${ }^{4}$. Ponadto, globalistyczna nauka jawić się może jako jedyny słuszny kierunek w rozwoju społeczności akademickich, ponieważ posiada największy potencjał modernizacyjny $i$ adaptacyjny.

Elementy, które pozwoliły na wytworzenie się w Polsce jakości, nazwanej przez autora niniejszego artykułu, ideą nauki globalistycznej sa:

- $\quad$ kapitalizm (w wersji „,reganowsko-tacherowskiej”), który został implementowany w Polsce podczas transformacji ustrojowej,

- liberalizm polityczny ${ }^{5} \mathrm{i}$ jego wartości ${ }^{6}$, reprezentowany przez dominującą opcję w polskim rządzie ${ }^{7}$,

- $\quad$ neoliberalizm gospodarczy, zaszczepiany przez oddziaływania globalnych korporacji oraz jego wpływ na instytucje edukacyjne ${ }^{8}$,

- $\quad$ przemiany kulturowe, $\mathrm{w}$ tym konsumpcjonizm, który jest częścią kultury Zachodu oraz bezpośrednim skutkiem kapitalizmu',

- $\quad$ przekonanie o tym, że nauka jest istotnym element rywalizacji gospodarczej między kluczowymi regionami świata (UE, USA, Chiny, Japonia, Indie, Korea) $)^{10}$,

- $\quad$ przekonanie o tym, że nauka powinna być polem konkurencji i rywalizacji uczelni i uczonych na całym świecie $^{11}$,

- $\quad$ przekonanie o tym, że nauka istnieje przede wszystkim jako narzędzie dostarczające praktycznych rozwiązań problemów ${ }^{12}$.

2 A. Kobylarek, Uniwersytet w komunikacyjnej sieci, [w:] Tenże, J. Semków (red.), Edukacja uniwersytecka w warunkach zmiany kulturowej, Wrocław 2008 , s. $79-80$.

3 Najbardziej popularnymi jezykami w nauce sa: angielski, francuski, niemiecki, hiszpański i chiński.

4 Wiedza dotycząca tego, w jaki sposób pisać artykuł na najwyższym światowym poziomie obejmuje swoim zakresem takie sprawy jak: struktura wypowiedzi, jakość dobranej literatury, przytoczone w pracy nazwiska, ilość samodzielnie włożonej pracy w autorskie dzieło (powszechnie stosowaną praktyką na zachodzie jest tworzenie zespołów badawczych, które nasteppnie tworzą wspólne artykuły), poziom podejmowanej refleksji, klarowność użytego języka wypowiedzi itd.

5 G. L. Gutek, Filozoficzne i ideologiczne podstawy edukacji, Gdańsk 2003, s. 173-190. Klasyczny liberalizm zorganizowany jest podhug trzech praw niezbywalnych każdej jednostce: prawa do życia, wolności i posiadania prywatnej własności. W warstwie ekonomicznej (normującej stosunki społeczne) dominującymi wartościami są: własność prywatna (egoizm), wolny rynek (konkurencja) i idea postępu. Warstwę polityczną (publiczna) reguluje laicyzacja, demokracja i indywidualizm.

6 E. Potulicka, Teoretyczne podstawy neoliberalizmu a jego praktyka, [w:] Tejże, J. Rutkowiak, Neoliberalne uwiklania edukacji, Kraków 2010, s. 40-42.

7 G. L. Gutek, dz. cyt., s. 151-153.

8 Analogiczna sytuację opisał Noam Chomsky w przypadku Meksyku, Chin, Tajlandii, Argentyny, Hiszpanii, krajów byłego bloku wschodniego, Afryki iAzji Środkowej. Zob. N. Chomsky, Zysk ponad ludzi: neoliberalizm a ład globalny, Wrocław 2000; N. Chomsky Rok 501: podbój trwa, Warszawa 1999; Zob. E. Potulicka, J. Rutkowiak, dz. cyt.

9 Nowy ład społeczny stworzył popyt na nowy model jednostki (bardziej nastawionej na siebie) i obywatela (traktujacego siebie jako członka wspólnoty pan-narodowej). Zmieniły się wartości, modyfikacji uległy tradycje, przemianie uległ model socjalizacji (przytoczenie literatury potwierdzające wymienione konkluzje z tego przedmiotu badań wypełniłoby cały tekst tego artykułu, a nawet i całej publikacji).

10 Deklaracja Bolońska. Szkolnictwo Wyższe w Europie, s. 1. http://ekspercibolonscy.org.pl/sites/ekspercibolonscy.org.pl/files/1999 PL Bologna_Declaration.pdf, 12.11.2013.

11 Tamże, s. 1

12 W. Wierżyński. Nauka i jej znaczenie dla innowacyjnej gospodarki, http://www.pi.gov.pl/PARP/chapter_86196.asp?soid=DEAD5DDB5233464EB1C3AE016DF89461, 13.01.2013. 
Z powyższych jakości o charakterze ideologicznym powstał szereg faktycznych zjawisk, procesów i inicjatyw podjętych przez podmioty decyzyjne na szczeblu lokalnym (krajowym - polskim) i globalnym (międzynarodowym). Wśród nich wymienić można kolejno:

1. Szczebel globalny:

- $\quad$ Stworzenie Europejskiego Obszaru Gospodarczego (EOG) ${ }^{13}$,

- Strategia Lizbońska ${ }^{14}$,

- Deklaracja Bolońska15,

- Wytworzenie się popytu na model uniwersytetu 3GU (Third Generation University) ${ }^{16}$, których cechami charakterystycznymi sa: włączenie w globalne sieci komunikacyjne ${ }^{17}$, działalność rynkowa ${ }^{18}$ oraz usługowa ${ }^{19}$ oraz grantowy (w oparciu o źródła prywatne i publiczne) system pracy naukowejej,

- $\quad$ upadek uniwersytetów $2 \mathrm{GU}$ (Second Generation University) $)^{21}$,

2. Szczebel lokalny:

- $\quad$ rozwiązania prawne pozwalające na istnienie szkolnictwa prywatnego w Polsce (Ustawa z dnia 12 września 1990 r. o szkolnictwie wyższym; Dz. U. 199 nr 65 poz. 352 ; w tym o możliwości prowadzenia placówek niepublicznych i studiów zaocznych ${ }^{22}$,

- $\quad$ rozwiązania prawne narzucające mechanikę funkcjonowania jednostek $w$ instytucjach szkolnictwa wyższego (Ustawa z dnia 27 lipca 2005 r. Prawo o szkolnictwie wyższym; Dz. U. nr 167 poz. 1365; reguluje ona: angaż i awans naukowy, kierunkowe minima kadrowe, Krajowe Ramy Kwalifikacji, punktacja działalności naukowej uczonych oraz jednostek badawczych, algorytm wysokości przyznawanej dotacji na dydaktykę i badania itd.).

\section{KONSEKWENCJE I WSKAŹNIKI NAUKI GLOBALNEJ}

Gwałtowny rozwój techniki i technologii informacyjnych pozwolił na szybkie, tanie oraz prawie nieograniczone zarządzanie danymi. Fakt ten miał swój skutek w rewolucji informacyjnej, która dotknęła również środowisko akademickie. Łączy się on bezpośrednio z procesami globalizacyjnymi²3 ${ }^{23}$ które utworzyły nową jakość nauki, nie ograniczanej przez abstrakcyjne granice państw, realne granice fizyczne (położenie geograficzne) oraz ograniczenia komunikacyjne (zarówno gdy rozpatrujemy generowanie komunikatów, jak i ich odbiór). „Skurczenie się" świata spowodowało, że możliwe stało się tworzenie komparatystycznych modeli środowisk akademickich, które służyły wymianie doświadczeń, poprawie własnej technologii wytwarzania wiedzy naukowej oraz konkurencji i rywalizacji o pieniądze i prestiż. W naturalny spo-

13 Europejski Obszar Gospodarczy; http://pl.wikipedia.org/wiki/Europejski_Obszar_Gospodarczy, 12.11.2013.

14 Zob. A. Budzyńska, M. Duszczyk, M. Gancarz, E. Gieroczyńska, M. Jatczak, K. Wojcik, Strategia Lizbońska. Droga do sukcesu zjednoczonej Europy, Warszawa 2002, s. 4.

15 http://ekspercibolonscy.org.pl/sites/ekspercibolonscy.org.pl/files/1999_PL_Bologna_Declaration.pdf, 12.12.2013; J. K. Thieme, Szkolnictwo wyżze. Wyzwania XXI wieku. Polska - Europa - USA, Warszawa 2009. s. 128-130. Brak alternatyw wynika z faktu, że w Europie tylko państwowe (i nieliczne prywatne) uczelnie posiadały stosowny kapitał społeczny i kulturowy, by „pchnąć” wspólnotę europejską na nową drogę rozwoju technicznego i technologicznego. Rozwoju, który jest kluczowy w budowaniu potencjału gospodarczego w sektorze przemysłu i usług (szczególnie niszy edukacyjnej i IT). Oczywiście przyniosło to szereg pozytywnych zmian, wśród których warto odnotować konieczność państwowego finansowania nauki na poziomie 3\%PKB (przez każdy z krajów członkowskich EU), jednak interesowna inwestycja jest sprzężona z wymaganiami wobec środowiska akademickiego. Standaryzacja pracy, ewaluacja programów studiów i modernizacja modelu zarządzania „tradycyjnymi” uczelniami była nieuchronna. Analogicznie jak w USA i Azji, szkolnictwo wyższe w Europie stało się oficjalnie częścią struktury społecznej, rynkowej i gospodarczej ze wszystkimi tego konsekwencjami, które jesteśmy obecnie w stanie zaobserwować.

16 Zob. J. G. Wissema, Uniwersytet Trzeciej Generacji. Uczelnia XXI wieku, Zębice 2009.

17 A. Kobylarek, Uniwersytet w komunikacyjnej sieci, [w:] Tenże, J. Semków (red.), dz. cyt. s. 90-92.

18 D. A. Hejwosz, Uniwersytet jako fabryka i supermarket. Kierunki, szanse i zagrożenia wynikające z komercjalizacji uniwersytetu, [w:] A. Kobylarek, J. Semków (red.), dz. cyt., s. 48-49.

19 T. Pomianek, Uczelnia i rynek pracy - w poszukiwaniu utraconej synergii, [w:] J. Chłopecki (red.), Uniwersytet, spoleczeństwo, gospodarka, Rzeszów 2006, s. 85. Absolwenci kierunków humanistycznych i społecznych znajdują zatrudnienie przede wszystkim w sektorze usług, który w post-industrialnych społeczeństwach wytwarza minimum 65\% PKB. zob. Ministerstwo Gospodarki, Ewolucja sektora ushug w Polsce w latach 1990 - 2008, Warszawa 2010 , s. 13.

20 Model taki określany jest mianem strategii dwutorowej. Zob. G. Wissema. dz. cyt., s. 128.

21 I. Zakowicz, Idea uniwersytetu Wilhelma von Humboldta - kontynuacja czy zmierzch, „Ogrody Nauk i Sztuk” 2012, s. 68.

22 Fakt zaistnienia konkurencyjnej sieci instytucji pozbawił monopolu dotąd uprzywilejowane placówki państwowe. Rzesze studenckie wcześniej pozbawione kapitału kulturowego i społecznego, ponadto ograniczane limitem przyjęć, mogły spełniając kryteria finansowe uzyskać dostęp do kształcenia akademickiego. Gwałtownie rozwijająca się sieć placówek prywatnych, spowodowała gwałtowny wzrost liczby studentów i absolwentów edukacji wyższej oraz sprzężony z tym proces dewaluacji dyplomu ukończenia studiów, który miast stać się kredencjałem (towarem wymiennym) przyją rolę,,potwierdzacza” potencjalnie posiadanych kwalifikacji i kompetencji. Nastąpiło ciekawe przejście rewolucyjne edukacji akademickiej z jej charakteru kredencjalistycznego na merytokratyczny.

23 Internet, międzynarodowe korporacje gospodarcze (ekonomiczny post-fordyzm), wspólnoty państw (UE, ONZ, NATO, NAFTA itd.), rozwój środków komunikacji oraz transportu.

Ogrody NAUK I SZTUK NR 2014 (4) 
sób powstały instytucje (np. Thomson Reuters, Ernst\&Young), których głównym celem stało się gromadzenie danych na temat placówek akademickich, w celu tworzenia raportów i list rankingowych. Rzeczywista wartość poznawcza owych dokumentów, bądź rankingów jest dyskusyjna ${ }^{24}$.

Chciałbym nadmienić, iż opisane wskaźniki arbitralnie służą funkcjonalnemu celowi oceny, systematyzacji i stratyfikacji środowisk akademickich na całym świecie. Dokonuje się ona na potrzeby podmiotów reprezentujących świat akademicki inter-muros ${ }^{25}$. Zewnętrzni interesanci mogą dzięki nim szybko i efektywnie zorientować się w wartości poszczególnych środowisk uczonych na świecie. Wśród najważniejszych globalnych mierników pracy naukowej można wyszczególnić:

- międzynarodowe rankingi uczelni (np. Lista Szanghajska),

- $\quad$ międzynarodowe rankingi czasopism (np. Lista Filadelfijska).

Wymienione elementy nie są wynikiem osobistej selekcji autora tekstu, lecz są społecznie powszechnie obowiązującym, przyjętym sposobem weryfikacji jakościowej każdego środowiska akademickiego na świecie ${ }^{26}$.

Lista Szanghajska, która zawiera zestawienie najlepszych uczelni świata, przyporządkowuje wartości punktowe w oparciu o liczbę laureatów Nagrody Nobla, którzy są absolwentami, bądź są zatrudnieni na etacie w danej placówce. Ranking placówek akademickich ma za zadanie informować, która uczelnia jest najlepsza na świecie. W następstwie pociagając za sobą pozytywne skutki w postaci prestiżu (wszyscy ją znają), bogactwa (uczelnia przyciąga sponsorów) i „,władzy” (kreuje ona trendy badawcze będące w centrum zainteresowania). Na liście znajdują się dwie polskie uczelnie: Uniwersytet Warszawski i Uniwersytet Jagielloński. Zajmują one miejsce w czwartej setce, notując ciagły spadek. Niemniej, sam fakt obecności na Liście Szanghajskiej jest ogromna nobilitacją dla danej uczelni, co również przekłada się na realne korzyści na skalę lokalną. Zarówno UW jak i UJ są jednymi z najbardziej rozpoznawalnych oraz cenionych uniwersytetów w Polsce, zajmując czołowe miejsca w rankingach krajowych ${ }^{27}$.

Kontrowersyjne odczucia rodzą międzynarodowe rankingi czasopism. W kręgach naukowych powszechnie znanymi w Polsce są Lista Filadelfijska tworzona przez Thomson Reuters ${ }^{28}$ oraz European Research Index of Humanities (ERIH). Od niedawna dołączyła do nich również lista tworzona przez hiszpański instytut SCImago Lab, prowadzący badania nad twórczością naukową na świecie ${ }^{29}$. Niejednoznaczna wartość rankingów czasopism wynika z pewnego paradoksu, który ciężko jest wytłumaczyć30. Z jednej strony działalność publikacyjna jest koronną działalnością każdego uczonego. W im lepszych (bardziej prestiżowych) czasopismach dana osoba publikuje, tym bardziej jest rozpoznawalna w lokalnych i międzynarodowych kręgach badawczych. Zdawać się może, że ocena wartości placówki i uczonego poprzez pryzmat publikacji jest zatem zasadna. Aczkolwiek działalność publikacyjna nie jest jedyną aktywnościąjaką uczeni na całym świecie się zajmuja kształcą studentów, przygotowują wydanie publikacji, organizują konferencje, pozyskują granty na badania bądź działają społecznie.

Zastanawiająca jest zatem stworzona przez Ministerstwo Naukii Szkolnictwa Wyżzzego, Lista Ministerialna, zawierająca wykaz, w skład którego wchodzą czasopisma kategorii: A (z impact factor ${ }^{31}$ ), B (bez impact factor), C - Wykaz Pism Humanistycznych (ERIH - European Research Index of Humanities), oraz punktację publikacji, które nie wchodzą w zakres

24 Pozostaje ona dyskusyjna dla osób reprezentujących bezpośrednio świat akademickich tj. nauczycieli akademickich i uczonych (szczególnie tych, którzy reprezentują nauki społeczne i humanistyczne), dla których kwantyfikacja efektów ich pracy jest niemożliwa, a nawet szkodliwa, przez co rezerwa w stosunku do krajowych i międzynarodowych rankingów jest uzasadniona.

25 A. Kobylarek, dz. cyt., s. 79-82. Podmioty akademickiego extra-muros - zewnętrzni interesariusze świata akademickiego (studenci, sponsorzy, pracodawcy, politycy itd.); podmioty akademickiego intra-muros - wewnętrzni interesariusze świata akademickiego (np. naukowcy, dydaktycy akademiccy, doktoranci).

26 Zaznaczam iż narzędzia i środki stosowane przy ocenie każdej instytucji i każdego uczonego na świecie są subiektywnymi kryteriami, które absolutnie nie mają żadnej obiektywnej mocy, zatem nigdy nie będą one w stanie faktycznie oddać wartość obiektu, który podlega ocenie.

27 A. Wdowińska-Sawicka, Najlepsze uczelnie w Polsce 2013, http://www.perspektywy.pl/portal/index.php?option=com content\&view=article\&id=823 :najlepsze-uczelnie-w-polsce-2013\&Itemid=231, 14.01.2014.

$28 \mathrm{http} / /$ /ip-science.thomsonreuters.com/cgi-bin/jrnlst/jloptions.cgi?PC=master, 09.12.2013

$29 \mathrm{http} / /$ www.scimagolab.com/,09.12.2013.

30 Chciałbym zaznaczyć, że ów paradoks zaistniał na kanwie nauki polskiej i autor nie chce zajmować równie arbitralnego stanowiska w przypadku innych państw europejskich i świata.

31 Impact Factor - jest to wartość określająca istotność wkładu artykułów zamieszczanych na łamach danego czasopisma w rozwój nauki. Mierzona jest ona liczbą cytowań danego autora i jego tekstu. Dla każdego tekstu, w skali rocznej wyliczana jest średnia ilość cytowań. Dokonywane jest to w oparciu o zasoby baz danych Journal Citation List (JCR), które zawierają indeksowane publikacje. Po czym zestawia się ilość cytowań wszystkich autorów, wyciaga z nich średnia arytmetyczną i tym jest właśnie impact factor. Szczegółowe dane zawierające listę czasopism oraz ich punktację znaleźć można na: http://www.nauka.gov.pl/listaczasopism-punktowanych/lista-czasopism-punktowanych.html. 
wyżej wymienionych kategorii czasopism. Utworzony ranking ma służyć punktacji działalności publikacyjnej instytutów, co w dalszej kolejności przekłada się na przyszłe finansowanie ze skarbu państwa działalności naukowej danej placówki. Sam pomysł jest bardzo funkcjonalny i posiada ogromny potencjał modernizacyjny, z tym, że kilka szczegółów powoduje iż:

- $\quad$ bardziej faworyzowane (wyżej punktowane) są publikacje w wydawnictwach zagranicznych niż krajowych (nawet tych najlepszych),

- $\quad$ bardziej faworyzowane są publikacje w powszechnym języku obcym (np. angielskim) niż narodowym (polskim),

- bardziej opłacalne jest masowe publikowanie krótkich artykułów niż obszernych monografii,

- przy grantowym systemie dystrybucji środków $\left(\mathrm{NCN}^{32}, \mathrm{NCBR}^{33}\right)$ na badania bardziej faworyzowana jest działalność (zarówno uczonego lub jeśli jest doktorantem to promotora uczonego) w skali międzynarodowej niż krajowej,

- porównując wartości punktowe za gratyfikowane działalności uczonego, najbardziej „opłacalne” jest publikowanie krótkich artykułów w najbardziej prestiżowych czasopismach krajowych bądź jakichkolwiek zagranicznych, co skutkuje tym, iż działania publikacyjne na skalę lokalną tracą rację bytu ${ }^{34}$.

Autor proponuje własny model działalności publikacyjnej, który ułatwi zrozumienie nie tylko mechanizmu konkurencji i rywalizacji między czasopismami, uczonymi oraz najważniejszymi regionami gospodarczymi świata, lecz również pokaże jak wszechstronnym, skutecznym i totalnym narzędziem globalnej oceny pracy uczonych na świecie są rankingi czasopism.

Rysunek 1. Model nauki globalnej

Zródło: opracowanie własne.

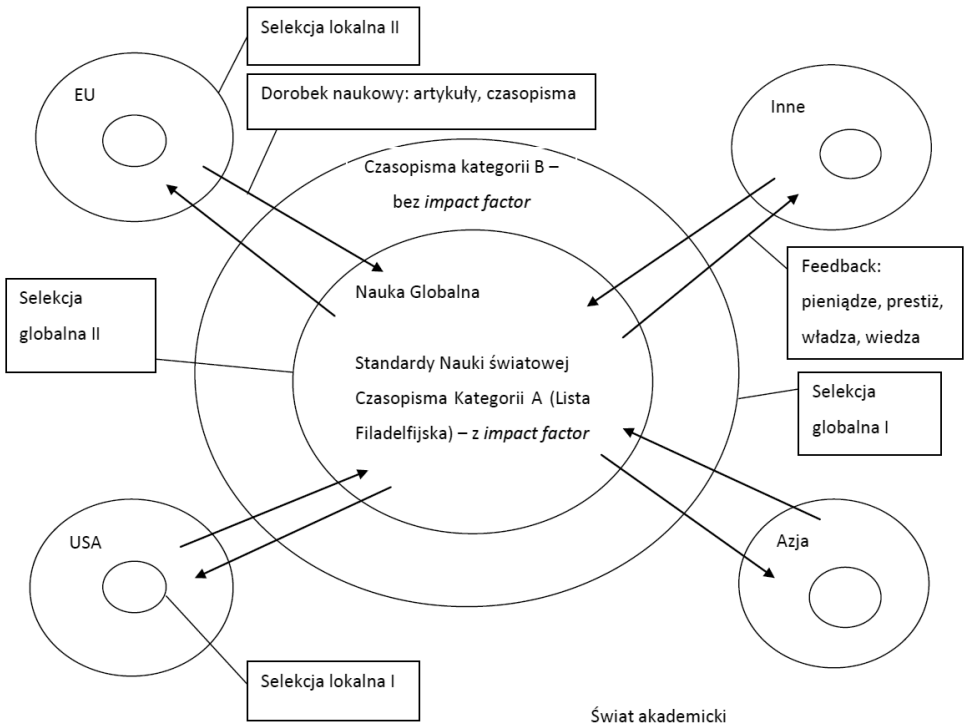

W Tabeli 1. zawarte jest wyjaśnienie poszczególnych zagadnień i elementów znajdujących się w diagramie zawierającym model nauki globalnej (Rys 1.). Rysunek sam w sobie stanowi raczej syntetyczny graf, który niestety nie jest w pełni możliwy do zrozumienia bez krótkiego rozwinięcia.

32 http://www.ncn.gov.pl/,09.12.2013

$33 \mathrm{http}: / /$ www.ncbir.pl/,09.12.2013.

34 Wyjątkiem może być początkowa działalność naukowa w przypadku studentów lub doktorantów, którzy dopiero budują swój kapitał naukowy.

OGRODY NAUK I SZTUK NR 2014 (4) 
Tabela 1. Model nauki globalnej-legenda

\begin{tabular}{|c|c|c|}
\hline Etap & Narzędzia i czynniki selekcji (na przykładzie EU) & $\begin{array}{c}\text { Potencjalna skala badań i jej badawcza } \\
\text { wartość międzynarodowa }\end{array}$ \\
\hline Selekcja lokalna I & Wymagania formalne czasopisma & Krajowa/niska \\
\hline Selekcja lokalna II & $\begin{array}{c}\text { Wymagania formalne czasopisma, język (francuski, } \\
\text { chiński, niemiecki, angielski, hiszpański, włoski - } \\
\text { najbardziej popularne) }\end{array}$ & Międzynarodowa/ niska \\
\hline Selekcja globalna I & $\begin{array}{c}\text { Wymagania formalne czasopisma, język angielski (na } \\
\text { tym etapie jest on najbardziej uniwersalnym językiem } \\
\text { nauki) }\end{array}$ & Międzynarodowa/wysoka \\
\hline Selekcja globalna II & $\begin{array}{c}\text { Wymagania formalne czasopisma, język, } \\
\text { prestiż w środowisku uczonych (np. na } \\
\text { "Liście Filadelfijskiej” publikować mogą tylko } \\
\text { "scientobryci”35) }\end{array}$ & \\
\hline
\end{tabular}

Źródło: Opracowanie własne.

Odpowiedzialność za powyższe rozwiązanie systemowe ponosi nie rząd uchwalając stosowne rozwiązania prawne, lecz idea globalistycznej nauki oraz brak alternatywnej wizji działalności świata uczonych. Autor nie neguje wartości tak wypracowanej mechaniki działalności naukowej, tym bardziej, iż nie ma ona mocy do siłowego egzekwowania na badaczach określonej strategii rozwoju ich kariery naukowej. Sugerowana jest przez autora natomiast interpretacja faktu zaistnienia Listy Ministerialnej, jest ona bowiem w jego ocenie efektem nadmiernego skupienia na międzynarodowych rankingach czasopism i stanowi pierwsze z serii narzędzi kwantyfikacji pracy uczonych, co może pociagać za sobą dalsze konsekwencje w świecie akademickim.

\section{KONSEKWENCJE GLOBALISTYCZNEGO MODELU NAUKI}

Wśród skutków implementacji globalistycznej idei nauki w strukturach ładu akademickiego w Polsce wymienić należy: zmiany ilościowe w kontekście produkcji publikacji naukowych, stratyfikację uczonych oraz uczelni na świecie, urynkowienie edukacji akademickiej, umasowienie edukacji akademickiej, powstanie zapotrzebowania na „scientobrytów” w Polsce ${ }^{36}$.

O zjawiskach umasowienia jak również urynkowienia edukacji akademickiej napisano pokaźną liczbę książek i artykułów, zatem nie są konieczne dalsze wyjaśnienia powyższych kwestiii ${ }^{37}$. Potrzebne jest natomiast rozwinięcie pozostałych punktów w celu wykluczenia możliwości nadinterpretacji. Wskazane jest przytoczenie danych ilościowych, które uwiarygodnią pierwszą z wyżej postawionych tez (umasowienie publikacji naukowych). Autor ponadto wprowadza nowe pojęcie scientobryty, które wymaga dookreślenia, aby w pełni oddać wartość i sens użytego terminu.

\section{UMASOWIENIE DZIAEALNOŚCI PUBLIKACYJNEJ}

Jak zostało wcześniej opisane, działalność w postaci tworzenia publikacji, jest koronną aktywnością każdego uczonego. Stanowi ona jedyny w pełni akceptowany i najbardziej skuteczny sposób wyrażania oraz wymiany myśli. Zmiany, które zachodzą na polu publikacyjnym, tak samo jak na kanwie prowadzenia badań, są kluczowe z perspektywy realizacji podstawowych zadań nauki i szkolnictwa wyższego.

Dane ilościowe zostały pozyskane ze strony SCImago Lab38. Dotyczą dokumentów, które są zarejestrowane w JCR (Journal Citation Report). W celu zbudowania całościowej wizji konieczne jest umieszczenie tych danych w zestawieniu z analogicznymi wartościami dotyczącymi trzech najważniejszych, z perspektywy polskiej, "graczy globalnych": USA, Europy Zachodniej (obszar EU bez Polski) i Azji. Jako zmienne posłużą dane zawierające (w nawiasie znajduje się użyty symbol tabelaryczny):

- całkowitą (zindeksowanych w JCR) liczbę dokumentów naukowych opublikowanych w wybranych regionach świata - D,

35 Pojęcie stworzone i wprowadzone przez autora niniejszego tekstu. Pełne rozwinięcie pojęcia znajduje się w niniejszym tekście w podrozdziale pt. „Scientobrytyzm”.

36 Scientobryta (ang. scielebrity) - pojęcie łączy dwa desyganty: naukę (sciente) i celebryte.

37 Zob. S. Kozyr-Kowalski, Uniwersytet a rynek, Poznan 2005.

38 http://www.scimagojr.com/, 09.12.2013. 
- liczbę dokumentów naukowych z zakresu nauk społecznych i humanistycznych ${ }^{39}$ opublikowanych w wybranych regionach świata - $\mathrm{D} ; \mathrm{S}+\mathrm{H}$,

- liczbę cytowanych dokumentów naukowych z zakresu nauk społecznych. i humanistycznych. w wybranych regionach świata- $\mathrm{CD} ; \mathrm{S}+\mathrm{H}$,

- $\quad$ wskaźnik cytowań dokumentów naukowych z zakresu nauk społ. i hum. w wybranych regionach świata WCD; S+H,

- $\quad$ liczbę cytowań przypadającą na jeden dokument ( $\mathrm{p}$ - per dokument) naukowy z zakresu nauk społ. i hum. w wybranych regionach świata $-\mathrm{CpD} ; \mathrm{S}+\mathrm{H}$,

- $\quad$ wskaźnik określający poziom autocytacji w naukach społ. i hum. w wybranych regionach świata, AC; S+H,

- $\quad$ wskaźnik określający poziom autocytacji w naukach społecznych w wybranych regionach świata, przypadający na jeden dokument naukowy $-\mathrm{ACpD} ; \mathrm{S}+\mathrm{H}$.

Dane obejmują swoim zakresem wyłącznie rok 1996 (data symboliczna - nastąpiła formalna komercjalizacja studiów w Polsce) i 2012. Są one wystarczające, aby ukazać wyraźną różnicę ilościową i jakościową w produkcji dokumentów naukowych, jaka się dokonała się na przestrzeni szesnastu lat w Polsce i najważniejszych „zagłębiach produkcji” wiedzy naukowej.

Tabela 2. Dane ilościowe dotyczące wytwórczości naukowej wybranych regionów świata

\begin{tabular}{|c|c|c|c|c|c|c|c|c|}
\hline & \multicolumn{9}{|c|}{ Wybrane regiony świata } \\
\cline { 2 - 10 } & \multicolumn{2}{|c|}{ Polska } & \multicolumn{2}{c|}{ USA } & \multicolumn{2}{c|}{ Region Azjatycki } & \multicolumn{2}{c|}{ Europa Zachodnia } \\
\hline Zmienne/Rok & 1996 & 2012 & 1996 & 2012 & 1996 & 2012 & 1996 & 2012 \\
\hline $\mathrm{D}$ & 11.504 & 31.948 & 329.834 & 537.308 & 163.495 & 767.503 & 339.383 & 677.115 \\
\hline $\mathrm{D} ; \mathrm{S}+\mathrm{H}$ & 101 & 632 & 11.301 & 36.056 & 1.246 & 14.605 & 6.220 & 36.946 \\
\hline $\mathrm{CD} ; \mathrm{S}+\mathrm{H}$ & 99 & 599 & 11.175 & 33.110 & 1.214 & 13.928 & 6.175 & 34.347 \\
\hline $\mathrm{WCD} ; \mathrm{S}+\mathrm{H}$ & 1.072 & 104 & 173.720 & 8.252 & 10.246 & 2.313 & 69.555 & 8.746 \\
\hline $\mathrm{CpD} ; \mathrm{S}+\mathrm{H}$ & 10.614 & 0.165 & 15.372 & 0.229 & 8.223 & 0.158 & 11.182 & 0.237 \\
\hline $\mathrm{AC} ; \mathrm{S}+\mathrm{H}$ & 173 & 45 & 104.603 & 5.482 & 4.536 & 1.463 & 38.714 & 6.131 \\
\hline $\mathrm{ACpD} ; \mathrm{S}+\mathrm{H}$ & 8.901 & 0.093 & 6.116 & 0.077 & 4.583 & 0.058 & 4.958 & 0.071 \\
\hline
\end{tabular}

Źródło: Opracowanie własne na podstawie danych zebranych ze strony Instytutu Badawczego SCImago Lab. Legenda: D - całkowita liczba dokumentów; D; S+H - całkowita liczba dokumentów z zakresu nauk społ. i hum.; CD; S+H - liczba cytowanych dokumentów z zakresu nauk społ. i hum.; WCD; S+H - wskaźnik cytowań dokumentów z zakresu nauk społ. i hum.; CpD; S+H - liczba cytowań przypadająca na jeden dokument z zakresu nauk społ. i hum; AC; S+H - wskaźnik autocytacji w naukach społ. i hum.; ACpD; S+H - wskaźnik autocytacji przypadający na jeden dokument.

Wnioski pierwotne dotyczące danych w Tabeli 2. są następujące: istotny wzrost rocznej produkcji dokumentów naukowych w Polsce i na świecie, istotny wzrost liczby cytowalności dokumentów naukowych tworzonych w Polsce, znaczne obniżenie się wskaźnika cytowalności dokumentów naukowych w Polsce i na świecie, znaczny spadek liczby cytowań przypadających na jeden dokument naukowy w Polsce i na świecie, znaczny spadek szkodliwego z perspektywy naukowej ogólnego zjawiska autocytacji w Polsce i na świecie, istotny spadek szkodliwego z perspektywy naukowej zjawiska autocytacji przypadającej na jeden dokument $w$ Polsce i na świecie.

Pozwala to na dalsze interpretacje, mianowicie: istotny wzrost ilości publikowanych dokumentów naukowych w Polsce i na świecie, postępująca egalitaryzacja ilościowa i jakościowa trzech najważniejszych naukowych regionów świata (Europa, Azja, USA), obniżenie sięjakości dokumentów naukowych tworzonych w Polsce i na świecie kosztem ilości produkowanych dokumentów (niski wskaźnik cytowalności poszczególnego dokumentu naukowego), rozbicie separatystycznych postaw uczonych wybranych regionów świata na rzecz współpracy międzynarodowej, co skutkuje przesunięciem bądź rozproszeniem zakresu władzy (monopolu) i prestiżu na wielu "graczy" uczestniczących w produkcji wiedzy naukowej.

39 SCImago Lab nie rozdzieliło dyscyplinarnie nauk społecznych i humanistycznych. Opatrzyło je wspólną nazwą Social Sciences (Nauki Społeczne). W ich zakres weszły takie dyscypliny wiedzy jak: Antropologia, Archeologia, Komunikacja, Studia nad Kulturą, Demografia, Rozwój, Edukacja, Studia Gender, Geografia i Planowanie (Logistyka), Zdrowie (z perspektywy społecznej), Ergonomia i Czynnik Ludzki, Prawo, Nauki Biblioteczne i Informacyjne, Studia Lifespan i Life-course, Lingwistyka i Studia Językowe, Nauki Polityczne, Stosunki Międzynarodowe, Administracja Publiczna, Bezpieczeństwo, Praca Socjalna, Socjologia i Nauki Polityczne, Studia nad Transportem, Urbanistyka.

Ogrody NAUK I SZTUK NR $2014(4)$ 
Podsumowując, polskie rozwiązania ustawowe przyniosły dwojakie skutki dla działalności publikacyjnej w Polsce. Spowodowały realny wzrost produkcji liczby artykułów oraz teoretyczny wzrost wartości polskiej nauki jako całości. Obniżyły jednak wartość każdej pojedynczej publikacji naukowej z zakresu nauk społecznych oraz humanistycznych. Łącząc ten fakt ze zjawiskiem obecnej niekorzystnej narracji dotyczącej działalności naukowej uczelni humanistycznych i społecznych tworzy to bardzo niekorzystne warunki uczonym reprezentującym dyscypliny akademickie klasyfikowane jako humanistyczne i społeczne.

\section{STRATYFIKACJA UCZELNI I UCZONYCH}

Opisywana wcześniej Lista Szanghajska zawiera zestawienie najlepszych i najważniejszych uczelni na świecie. Można dokonać interpretacji, iż jest ona efektem procesów stratyfikacyjnych w świecie akademickim w skali makro ${ }^{40}$. Autor jednak „odwraca tok wnioskowania” proponując podejście indukcyjne, startując z poziomu mikro-strukturalnego, czyli jednostki. Głównymi wskaźnikami w oparciu o które dokonywane jest obecnie uwarstwienie pojedynczych uczonych, sa:

1. Placówka:

- Jaka to uczelnia? (uniwersytet, wyższa szkoła zawodowa, politechnika, prywatna, publiczna),

- Gdzie założona? (kontynent, region, kraj, miasto globalne, małe miasteczko, powszechnie rozpoznawalne miasto),

- Kogo skupia? (wielu znanych naukowców, brak znanych naukowców),

- Jak bardzo uczelnia ma ugruntowaną pozycję w rankingu krajowym i międzynarodowym?

2. Publikacje:

- Gdzie są publikowane? (czasopisma krajowe, czasopisma zagraniczne, czasopisma kategorii A) - łączy się z tym kryterium jakości dorobku,

- Ile prac jest publikowanych przez autora? - punktacja jest sumowana w skali rocznej,

- Dla kogo publikowane? (pisma ogólno-tematyczne, pisma branżowe),

3. Kapitał kulturowy i społeczny uczonego:

- Skąd pochodzi?

- Jakie sąjego możliwości finansowe?

- Jaki jest jego potencjał intelektualny?

- Jaką dziedzinę nauki reprezentuje?

Największą siłą (z perspektywy rozwoju naukowego) i słabością (z perspektywy strukturalno-funkcjonalnej) jest niejednorodność uczonych jako grupy społecznej. Pierwotny jak i wtórny kapitał społeczny i kulturowy - oraz ich pochodna - kapitał ekonomiczny, są kluczowe w możliwościach poruszania się po strukturze świata akademickiego. Koszt uczestnictwa w konferencji bądź odpłatność za publikację artykułu w renomowanym czasopiśmie, są równie skutecznym narzędziem selekcji kandydatów, jak ocena jakościowa danego artykułu bądź nieformalna sieć kontaktów, jakie się posiada.

Oczywistym jest zatem, że szanse dla wszystkich naukowców nie sąjednakowe, ponieważ pochodzą oni z różnych kontynentów, kultur, krajów, rodzin, miast i środowisk społecznych. Powoduje to również, że ich sieci kontaktów nie są jednorodne, co więcej, nie posiadają tożsamej wartości społecznej. Przykładowo, grupa wrocławskich naukowców ma bardziej ograniczone możliwości działania, w kontekście całej nauki globalnej, niż grupa naukowców np. z Berlina, Oxfordu, Londynu, Princeton, Yale, Harvardu i Massechusets Institute of Technology ${ }^{41}$. Prestiz zestawianych środowisk jest nierówny, zatem szanse na dokonywanie dalszych odkryć w perspektywie globalnej równieżjest odmienny. Gdy działalność placówki oceniania jest w perspektywie globalnej (wybierając opcję lokalną uczelnia skazuje się na prowincjonalizm i jedynie walczy o to, by trwać), ważny jest jej początkowy kapitał, którym wspomoże uczonego w jego pracy, bo od niego zależy status i przyszłość uczelni. Uczelnie polskie w zestawieniu z placówkami z USA, Azji bądź znaczniejszych jednostek badawczych europejskich, posiadają ów kapitał bardzo ograniczony. W konsekwencji każdy polski uczony startujący w wyścigu do sławy, pieniędzy i wiedzy ma gorszy start ku profesjonalizacji naukowej niż jego kolega z Gorgetown, Yale, Todai, bądź École Normale Supérieure. Tak wytworzony początkowy układ, $\mathrm{w}$ którym ambicje rządu przesłoniły racjonalne kalkulacje, może skazać cała naukę polską na margines świata akademickiego i na wstępie wytworzył on ogromne bariery, których pokonanie uniemożli-

40 Tak samo jak w przypadku stratyfikacji społecznej wiążą się z tym takie zjawiska jak: nierówność, rywalizacja, walka o dostęp do dóbr tj. bogactwo, władza, prestiż, hierarchizacja, reprodukcja struktury wytworzonej w toku stratyfikacji itd.

41 Autor jest świadom niesprawiedliwości zestawienia na niekorzyść Uniwersytetu Wrocławskiego, lecz nie widzi również zasadności przekreślenia takiego porównania. Tym bardziej, że obecne ambicje środowisk naukowych w Polsce, wzmacniane odpowiednią polityką zarządzania ze strony Ministerstwa Edukacji i Szkolnictwa Wyższego, są w swej jawnej warstwie, światowe. Słowem, celem jest dołączenie do czołówki w perspektywie międzynarodowej, a fakt pochodzenia uczonych z rożnych organizacyjnie placówek (publiczne, prywatne) nie jest istotny, ponieważ liczy się ich dorobek naukowy, który są w stanie wygenerować. 
wia dodatkowo anachroniczny model socjalizacji uczonych oraz również nieracjonalny model zarządzania uczelniąa .

Można zatem przypuszczać, że sława uczonych bądź placówki jest wprost proporcjonalna do ilości i jakości sponsorów, którzy w daną placówkę chcą inwestować (bez względu na to czy jest to sponsor publiczny czy prywatny). Określone możliwości finansowe przekładają się na skalę i jakość prowadzonych badań. W dalszej perspektywie stanowi to kluczowy element stratyfikacji uczelni na całym świecie i uczonych, którzy są w nich zatrudnieni.

\section{"SCIENTOBRYTYZM"}

„SCientobrytami" świata akademickiego nazywaćnależy wybitnejednostki świata naukił ${ }^{33}$. Są najczęściej cytowani, najbardziej rozpoznawalni, najbardziej pożądani w środowisku naukowym i poza nim. Ich teorie są najbardziej „żywotne” z czasem stając się elementem kanonu dyscyplinarnego. Skutkuje to ich ogromną wartością społeczno-rynkową oraz szerokim spectrum oddziaływania na wielu płaszczyznach, na równi $\mathrm{w}$ „światku” akademickim oraz poza nim. Cieszą się najwyższym prestiżem, który może mieć dwa źródła: 1) w ciaggym tworzeniu modnej i innowacyjnej wiedzy, 2) w „odcinaniu kuponów" od własnej wcześniej ugruntowanej pozycji (np. stopień naukowy) w środowisku naukowym i poza nim. Scientobrytami można również określić uczonych, których kolokwialnie określilibyśmy pojęciem, „modnych”, których jednorazowe dokonanie bądź pokaźny dorobek spowodował, iż stali się bardziej rozpoznawalni niż inni ich koledzy w środowisku świata nauki. Ich nazwisko staje się „marką samą w sobie”, która przyciaga atencję innych uczonych, instytucji prywatnych, publicznych oraz mediów.

Wartość scientobrytów w ocenie autora jest w obecnych realiach nowego ładu akademickiego nie do przecenienia, dzięki temu, że przyciagają oni innych znakomitych uczonych, najlepszych studentów i sponsorów oraz sygnują markę uczelni, w której aktualnie się znajdują. Za życia wokół nich organizowane są katedry, a nawet wydziały, po śmierci nobilitują oni daną uczelnię faktem, że w niej uczyli, wykładali i działali.

Scientobrytą nie jest jednak każdy uczony o tytule profesora, choć takim osobom łatwiej nimi zostać. Do tego by dana osoba stała się scientobrytą potrzebne są: indywidualne predyspozycje jednostki (inteligencja, komunikatywność, ambicja, dokonania), odpowiednie otoczenie (zasoby materialne i ludzkie uczelni), zainteresowanie mediów (dana osoba jest w stanie skupić na sobie ich uwagę) oraz, co bardzo ważne, uznanie w środowisku naukowym. Nie jest to więc dzieło przypadku, tylko splot wielu czynników, na które dana jednostka ma wpływ.

W obecnych czasach, gdy uczelnie muszą rywalizować o studentów oraz środki na badania, słusznym może być wniosek, iż to scientobryci skutecznie podnoszą szanse uczelni oraz innych uczonych z tej samej placówki na stały napływ kandydatów na studia oraz spore zasoby finansowe służące celom badawczym.

\section{Podsumowanie}

Dotychczas prowadzone wnioskowanie oraz przytoczone dane pozwoliły na udzielnie odpowiedzi na pytanie główne, które brzmiało: Jakie konsekwencje dla ładu akademickiego w Polsce wygenerowała globalistyczna idea nauki?

Odpowiedź jest złożona, więc warto podzielićją na dwie części: pierwsza będzie zawierała konsekwencje pozytywne, druga natomiast negatywne. Wśród konsekwencji pozytywnych można wymienić:

- $\quad$ istotny wzrost liczby produkcji publikacji naukowych w Polsce, co jest kluczowe w aktywnym partycypowaniu polskich uczonych w produkcji wiedzy naukowej,

- $\quad$ zbudowanie podstaw do wytworzenia się w Polsce uniwersytetów modelu 3GU,

- wykrystalizowanie się najlepszych ośrodków badawczych w Polsce, do których trafiają środki na działalność,

- $\quad$ konieczność centralizacji nauki polskiej zarówno w jej warstwie organizacyjnej, jak i kadrowej, konieczność podejmowania współpracy oraz rywalizacji międzynarodowej (dzięki rywalizacji w ocenie autora uruchamiane są procesy pro-jakościowe),

- $\quad$ ostatecznie wytworzenie się podstaw do płynnej, szybkiej i efektywnej oceny pracy danej placówki akademickiej, korzystając z międzynarodowych narzędzi w postaci rankingów uczelni i czasopism,

- powstanie popytu na „scientobrytów”, którzy nie tylko stanowią realną egzemplifikację wartości i potencjału jednostki na tle anonimowego społeczeństwa, lecz są pożądanym łącznikiem między obecną hiper-rzeczywistą

42 J. K. Thieme, dz. cyt, s. 369-375.

43 Uczonymi, których w ocenie autora, można określić tym mianem sąna świecie: Michael Sandel, Jürgen Habermas, Francis Fukuyama, Pierre Bourdieu, Steven Hawking, Micho Kaku lub Bertrand Russel. W przypadku gdy zawężamy krąg do skali krajowej scientobrytami można nazwać np.: Piotra Glińskiego, Jana Miodka, Zbigniewa Lwa-Starowicza, Leszka Kołakowskiego, Leszka Balcerowicza, Ryszarda Kapuścińskiego, Bronisława Malinowskiego.

Ogrody NAUK I SZTUK NR 2014 (4) 
"kulturą pop" i „instant” oraz konsumpcyjnie nastawionym społeczeństwem.

Wśród negatywnych konsekwencji można wymienić:

- umasowienie studiów oraz twórczości naukowej co pociaga za sobą dalsze zmiany zarówno dla jakości kształcenia, jak i działalności badawczej,

- upadek modelu uniwersytetu 2GU oraz redefinicja celów, zadań i obowiązów uczelni oraz uczonych,

- $\quad$ stratyfikacja uczelni oraz uczonych, co pociagga za sobą nierówny dostęp do władzy, prestiżu i bogactwa zarówno w skali instytucjonalnej oraz indywidualnej,

- marginalizacja oraz stygmatyzacja ośrodków skierowanych na działalność dydaktyczną bądź badawczą w skali lokalnej,

- $\quad$ konieczność rywalizacji i konkurencji między uczelniami i uczonymi, zamiast współpracy oraz swobodnej wymiany wiedzy.

Można postawić tezę, iż świat akademicki w Polsce został odgórnie włączony w struktury gospodarcze rodzimych i międzynarodowych społeczeństw, w wyniku czego uczestniczy w pełnej rywalizacji grze rynkowej, w której stawką są pieniądze, sława oraz władza. Jednostki, które nie wyrażają zgody na tak zarysowany ład, z oczywistych przyczyn quasi-naturalnie „wymrą" w ogromnych procesach strukturalnych globalnego świata akademickiego bądź zostaną zmarginalizowane i zapomniane. Przyszłość uczonych rysuje się w formie scientobryctwa.

Konformizm nakazuje dostosować się do reguł i zadań, jakie stawiane są uczonym i uczelniom. Pozostaje adaptacja do nowych zasad funkcjonowania oraz definiowania własnej roli oraz ambicji, które nabrały kontekstu globalnego. Przemawia również za tym fakt ogromnego kapitału finansowego jaki płynie zarówno ze strony rządowej, jak również świata biznesu na badania i usługi (oczywiśćie o określonym profilu). Dane ilościowe choć nie rozstrzygają wielu kwestii pokazują że obecne neoliberalne zasady sprzyjają produkcji wiedzy naukowej i to takiej, która ma coraz wyższąjakość. Uczeni całego świata zaczynają stawać się równorzędnymi partnerami i przeciwnikami dla siebie, aczkolwiek wypracowany na różnych gruntach kapitał lokalny zarówno jednostkowy, jak i instytucjonalny, jest bardzo istotny.

Autor nie chce dokonać oceny i wartościowania obecnie wytworzonego ładu społecznego i akademickiego. Wynika to ze złożoności i niejednoznaczności aksjonormatywnej wielu zjawisk oraz procesów, które można zaobserwować. Warto podkreślić, iż zmiany nie zachodzą tylko w Polsce, lecz na całym świecie, aczkolwiek problem ten daleko wykracza poza możliwości objętościowe niniejszego artykułu, jak również poznawcze autora tekstu. Dalsze osądy oraz rozważania o charakterze aksjologicznym autor pozostawia w gestii czytelnika.

\section{Bibliografia:}

[1] Biały K. Przemiany wspótczesnego uniwersytetu -od idei von Humboldta do modelu uczelni przedsiębiorczej. Łódź 2011.

[2] Budzyńska A, M. Duszczyk, M. Gancarz, E. Gieroczyńska, M. Jatczak, K. Wojcik, Strategia Lizbońska. Droga do sukcesu zjednoczonej Europy. Departament Analiz Ekonomicznych i Społecznych. Urząd Komitetu Integracji Europejskiej, Warszawa 2002.

[3] Chłopecki J., Uniwersytet, społeczeństwo, gospodarka, Rzeszów 2006.

[4] Goćkowski J., Uniwersytet i tradycje w nauce,. Kraków 1999.

[5] Gutek G. L., Filozoficzne i ideologiczne podstawy edukacii, Gdańsk 2003

[6] KobylarekA., Semków J., Edukacja uniwersytecka w warunkach zmiany kulturowej, Wrocław 2008.

[7] Malewski M., Teraźniejszość-Człowiek - Edukacja, Wrocław 2001.

[8] Thieme J. K., Szkolnictwo wrższe. Wyzwania XXI wieku. Polska - Europa - USA, Warszawa 2009.

[9] Ministerstwo Gospodarki.. Ewolucja sektora ustug w Polsce w latach 1990-2008, Warszawa 2010.

[10] Potulicka E., Rutkowiak J., Neoliberalne uwikłania edukacji., Kraków 2010.

[11] Solarczyk-Ambrozik E., Studia Edukacyjne, nr 22, Poznań 2012.

[12] Wissema J. G., Uniwersytet Trzeciej Generacji. Uczelnia XXI wieku, Zębice 2009.

[13] Zakowicz I., Idea uniwersytetu Wilhelma von Humboldta - kontynuacja czy zmierzch, „Ogrody Nauk i Sztuk” 2012.

\section{Netografia:}

www.scimagojr.com, 09.12.2013.

www.ncn.gov.pl, 09.12.2013.

www.ncbir.pl, 09.12.2013.

ip-science.thomsonreuters.com 09.12.2013

http://www.nauka.gov.pl/lista-czasopism-punktowanych/lista-czasopism-punktowanych.html. http://ekspercibolonscy.org.pl/sites/ekspercibolonscy.org.pl/files/1999_PL_Bologna_Declaration.pdf, 12.12.2013.

http://pl.wikipedia.org/wiki/Europejski_Obszar_Gospodarczy, 12.11.2013.

44 J. Wolszczak-Derlacz, Ksztalcić czy prowadzić badania naukowe? Analiza efektywności ksztalcenia i efektywności naukowej na przykładzie wybranych publicznych szkót wyższych w Polsce, [w: "Edukacja" 2013, nr. 2 (122), s. 27-28; R. Wawrzyniak-Baszterda, Oferta dydaktyczna uniwersytetu. Potencjat i ograniczenia dla ksztaltowania kapitahu społecznego w szkole wyższej, [w:] E. Solarczyk-Ambrozik, Studia Edukacyjne, nr. 22, Poznań 2012, s. $222-223$. 